\title{
Manajemen Strategik dan Mutu Pendidikan Islam
}

\author{
Aris Munandar \\ Sekolah Tinggi Ilmu Tarbiyah (STIT) Mamba'ul Ulum Jambi \\ Email: arism453@gmail.com
}

\begin{abstract}
A qualified education is an education which is able to develop nation character as well as civilization. Therefore, the values of faith, obedience, piousness, virtuous acts, healthiness, knowledge, competence, creativity, self-reliance, democracy and responsibility should be strengthened within educational institutions including students and stakeholders. Nowadays, most schools superficially develop some of the educational aspects, such as, cognitive dimension that is taught through memorizing and psychomotor dimension which is merely a mechanistic process. Meanwhile, other dimensions, such as relational dimension, are not handled properly. Ideally, a qualified school should be able to develop cognitive dimension, not only as a memorization but also as knowledge mastery suitable to students' capacity as well as their endowment. This study uses a qualitative descriptive analysis approach. From this phenomenon, I tried to offer a concept of implementation and development of Islamic education within strategic management framework related to teaching-learning process both in formal and non- formal schools. The aim is to fortify students so that they will keep holding onto Qur'an, Hadits, Ijma' and Qiyas in this global era. Core concept of the strategic management in Islamic education is indeed still novel. Therefore, it is expected that this article can be used in broader area of Islamic education. Moreover, it is also hoped that it will positively affect resources allotment effectiveness in order to achieve the objective of national education. One way is through SWOT analysis, so that institutions of the Islamic education will be able to produce well-qualified graduates who play significant roles in society. That Islamic education is really the solution to the diseases that afflict modern humans. Islamic education is education that is built on the basis of human nature. Which always aims to foster a total human personality in a balanced manner through spiritual, intellectual, self-rational practice, feelings and sensitivity of the human body.
\end{abstract}

Keywords: Strategic Management, Quality, Islamic Education

\begin{abstract}
Abstrak
Pendidikan yang bermutu adalah Pendidikan yang mampu mengembangkan kemampuan, membentuk karakter dan peradaban bangsa. Oleh karena itu harus dikembangkan dalam pendidikan disekolah maupun pesantren nilai-nilai keimanan, ketaqwaan, akhlak mulia, kesehatan, ilmu, kecakapan, kreativitas, kemandirian, demokrasi dan tanggung jawab pada anak didik dan seluruh stakeholders pendidikan. Kondisi Saat ini kebanyakan sekolah hanya mengembangkan aspek- aspek pendidikan
\end{abstract}

Nur El-Islam, Volume 6, Nomor 2, Oktober 2019 
secara dangkal: dimensi kognitif (hanya menghafal); dimensi ketrampilan (mekanistik); dimensi nilai tidak terurus dan tidak mendalam; dimensi hubungan (ranah interaktif) tidak tergarap. Padahal seharusnya sekolah berkualitas mampu mengembangkan dimensi kognitif (menguasai pengetahuan sesuai dengan bakat, minat siswa/i nya). Penelitian ini menggunakan kualitatif dengan pendekatan deskriftif analisis. Melihat fenomena tersebut penulis mencoba untuk menawarkan sebuah konsep, implementasi dan perkembangan pendidikan Islam dalam bingkai manajemen strategik, dalam proses pembelajaran di sekolah formal maupun non formal dengan tujuan membentengi siswa diera globalisasi agar tetap berpegang pada nilai-nilai qur'an, hadist, ijma' dan qiyas. Inti dari sebuah konsep manajemen strategik dalam pendidikan Islam memang merupakan hal yang baru sehingga harapan besar pada tulisan ini dapat digunakan di dunia pendidikan Islam yang lebih luas serta lebih mengefektifkan pengalokasian sumber daya yang ada dalam rangka mencapai tujuan pendidikan nasional. Salah satu caranya adalah dengan menggunakan teknik analisis SWOT. Jadi mutu lulusan pendidikan Islam tidak dipandang sebelah mata, justru sangat besar peranannya di lingkungan masyarakat. pendidikan Islam sesungguhnya adalah solusi bagi penyakit yang menimpa manusia modern. Pendidikan Islam adalah pendidikan yang dibangun atas dasar fitrah manusia. Yang senantiasa bertujuan menumbuhkan kepribadian total manusia secara seimbang melalui latihan spiritual, intelektual, rasional diri, perasaan dan kepekaan tubuh manusia.

Kata Kunci: Manajemen Strategik, Mutu, Pendidikan Islam.

\section{A. Pendahuluan}

Akhir-akhir ini mulai dikeluhkan tentang rendahnya mutu pendidikan. Kualitas hasil pendidikan di tengah masyarakat pada kenyataannya sekarang ini bukan saja diukur dari nilai ujian akhir atau besarnya Indek Prestasi yang dihasilkan. Terkait mutu pendidikan, masyarakat sudah mulai melihat dari seberapa jauh lulusan lembaga pendidikan mampu tampil di tengah-tengah kehidupan masyarakat.

Sekalipun angka hasil ujian akhir dan Indek Prestasi cukup tinggi, tetapi jika yang bersangkutan belum mampu memenangkan kompetisi dalam memperebutkan lapangan kerja dan apalagi menciptakannya sendiri, maka kualitas pendidikan dimaksud belum memenuhi harapan. Selama ini tolok ukur kualitas pendidikan sebatas dirupakan dalam bentuk angka-angka, tetapi sebenarnya hal itu belum mencukupi.

Tujuan pendidikan nasional kita yang berasal dari berbagai akar budaya bangsa Indonesia terdapat dalam UU Sistem Pendidikan Nasional, yaitu UU No. 20 Tahun 2003. Dalam UU Sisdiknas No. 20 
Tahun 2003 tersebut, dikatakan: "Pendidkan nasional bertujuan untuk berkembangnya potensi peserta didik agar menjadi manusia yang beriman dan bertakwa kepada Tuhan Yang Maha Esa, berakhlak mulia, sehat, berilmu, cakap, kreatif, mandiri, dan menjadi warga negara yang demokratis serta bertanggung jawab."

Dengan dasar tujuan nasional yang telah disuratkan dalam UU Sisdiknas No. 20 Tahun 2003 itu, setiap unit atau organisasi yang berhak dalam bidang pendidikan dalam menjabarkan kegiatannya mengacu pada tujuan pendidikan nasional. Tujuan pendidikan nasional ditentukan oleh pemerintah bersama Dewan Perwakilan Rakyat dengan memperhatikan masukan dari masyarakat atau para pakar yang berkompeten dan kemudian dirumuskan oleh pemerintah dan anggota DPR. Hasil rumusan tujuan pendidikan nasional tersebu tertuang dalam UU Sisdiknas No. 20 Tahun 2003. ${ }^{1}$

Pendidikan yang bermutu adalah pendidikan yang mampu mengembangkan kemampuan, membentuk karakter dan peradaban bangsa. Oleh karena itu harus dikembangkan di sekolah melalui aspek keimanan, ketaqwaan, akhlak mulia, kesehatan, ilmu kecakapan, kreativitas, kemandirian, demokrasi dan tanggung jawab pada anak didik dan seluruh stakeholders pendidikan.

Kondisi saat ini kebanyakan sekolah hanya mengembangkan aspek-aspek pendidikan yang dangkal : dimensi kognitif (hanya menghafal); dimensi ketrampilan (mekanistik); dimensi nilai tidak terurus dan tidak mendalam; dimensi hubungan (ranah intraktif) tidak tergarap. Padahal seharusnya sekolah berkualitas mampu mengembangkan dimensi kognitif (menguasai pengetahuan sesuai dengan bakat, minat siswa/i nya).

Persaingan dalam merebutkan objek pendidikan, sangat erat kaitannya dengan seseorang yang terjun dalam bidang pendidikan dalam mengenali selera pasar serta pemilihan strategi. Agar objek pendidikan loyal, maka harus mempunyai strategi guna mempertahankan mereka agar tidak lari dari pesaing-pesaing lain. Pendidikan pada hakikatnya merupakan proses pembebasan peserta

${ }^{1}$ M. Sukarjo dan Ukim Komarudin, Landasan Pendidikan Konsep dan Aplikasinya (Jakarta: PT Raja Grafindo Persada, 2010), h. 14-15. 
didik dari ketadak tahuan, ketidak mampuan, ketidak berdayaan, ketidak benaran, ketidak jujuran, dan dari buruknya hati, akhlak dan keimanan. ${ }^{2}$

Untuk itu proses pembelajaran tidak hanya menekankan pada hafalan dan latihan penguasaan soal-soal ujian. Proses pembelajaran yang demikian telah banyak menelan korban, dimana para lulusan hanya membawa selembar ijazah. Dibalik ijazah yang dimilikinya tidak mencermin adanya efek pada perubahan watak/kepribadian,pemikiran dan prilaku. ${ }^{3}$

Dalam bidang pendidikan, penulis sering memperhatikan bahwa pada beberapa tingkat sistem pendidikan di Indonesia baik di tingkat global, makro nasional, messo, maupun mikro memiliki kesaling terkaitan. Dalam konteks tersebut, kita perlu mengembangkan kerangka konseptual dalam bidang manajemen mutu, manajemen strategik, serta balanced Score Card (BSC) dan konsep Surfing on Chaos dan Blue Ocean Strategy. ${ }^{4}$

Substansi manajemen pendidikan yang lain, seperti manajemen keuangan, manajemen sarana dan prasarana, manajemen hubungan masyarakat dan manajemen layanan khusus seharusnya dipandang sebagai manajemen penunjang. Perhatian dan kepedulian yang terlalu berlebihan kepada salah satu substansi penunjang dalam aktualisasi manajemen pendidikan seringkali menimbulkan ketidakpaduan penyelenggara pendidikan yang berakibat ketidakpedulian aktualisasi manajemen pendidikan secara utuh. ${ }^{5}$

Pengaruh globalisasi tak bisa dihindarkan dari setiap organisasi untuk melakukan perubahan dan pembenahan dalam rangka mencapai tujuannya, baik organisasi usaha, organisasi sosial maupun organisasi pendidikan. Di dunia pendidikan, persaingan tak bisa dihindarkan dengan munculnya lembaga-lembaga pendidikan mulai dari play group/MDT, SD/MI, SLTP, MTS/ SLTA/MA sampai perguruan tinggi yang berlabel internasional. Tentu ini sebuah tantangan bagi dunia

${ }^{2}$ Dedi Mulyaa, Pendidikna Bermutu dan Berdaya Saing (Bandung: Rosda 2012), h. 2 cet. II

${ }^{3}$ Ibid, h. 2-3.

${ }^{4}$ Ibid., hal. 14-15.

${ }^{5}$ Wileam Mantja, “Manajemen Pendidikan dalam Era Reformasi” Jld. 7, no 2, h.93 
pendidikan kita untuk melakukan upaya-upaya penataan organisasi dalam rangka meningkatkan kualitas dan mutu pendidikan sesuai dengan tuntutan perubahan.

Faktor lingkungan internal dan eksternal perlu diantisipasi, dipantau, dinilai, dan disertakan sedemikian rupa ke dalam proses pengambilan keputusan eksekutif. Para pengambil keputusan, termasuk di dalamnya kepala sekolah maupun pengelola pendidikan lainnya seringkali terpaksa mengalahkan tuntutan kegiatan interen dan eksteren lembaga pendidikan demi melayani bermacam kepentingan seperti urusan rutin, dinas, bekerja harus selalu di bawah petunjuk atau pedoman kerja yang ditetapkan oleh birokrasi tanpa mempertimbangkan kebutuhan eksternal organisasi yang terus berubah, sehingga proses pengambilan keputusan seringkali tidak maksimal dalam menghasilkan keputusan-keputusan strategis. Akibatnya persoalan aktual lembaga pendidikan yang dihadapi tidak dapat terselesaikan secara maksimal.

Manajemen sekolah seyogyanya memahami perkembangan manajemen sistem industri modern, sehingga mampu mendesain, menerapkan, mengendalikan, dan meningkatkan kinerja sistem pendidikan yang memenuhi kebutuhan manajemen sistem industri modern. Hal ini dimaksudkan agar setiap lulusan dari sekolah mampu dan cepat beradaptasi dengan kebutuhan sistem industri modern. Dengan demikian pengembangan sistem pendidikan di sekolah perlu diketahui tentang konsep dasar sistem industri modern yang akan dipergunakan sebagai landasan utama untuk membahas penerapan TQM pada sistem pendidikan modern di Indonesia.

Kunci sukses yang harus dimiliki dan sekaligus merupakan daya saing yang paling efektif adalah mutu/kualitas. Siapapun yang memiliki kualitas maka peluang untuk dapat menjadi pemenang akan sangat terbuka. ${ }^{6}$ Oleh karena itu pendidikan harus dikelola dengan manajeman yang strategik agar dapat memilih di antara banyak manajemen yang baik untuk menghasilkan suatu manajemen yang paling baik untuk mencapai mutu pendidikan.

\footnotetext{
${ }^{6}$ H.B Siswanto, Pengantar Manajemen (Jakarta : Bumi Aksara, 2006), h.27
} 
Manajemen strategik adalah suatu seni (keterampilan), teknik, dan ilmu merumuskan, mengimplmentasikan, dan mengevaluasi serta mengawasi berbagai keputusan fungsional organisasi (bisnis dan non bisnis) yang selalu dipengaruhi oleh lingkungan internal dan eksternal, yang senantiasa berubah sehigga memberikan kemampuan kepada organisasi untuk mencapai tujuan sesuai dengan yang diharapkan. ${ }^{3}$ Pentingnya masyarakat dalam menentukan manajemen strategik menjadi sangat dominan, karena dapat menyebabkan suatu keunggulan atau bahkan dapat menjadi ancaman bagi lembaga pendidikan.

Peran lembaga pendidikan Islam dalam meningkatkan pendidikan sangatlah strategis, agar mendapatkan kepercayaan dari masyarakat. Tanggung jawab kepala madrasah yang utama ialah meningkatkan kurikulum sekolahnya. Hendaknya ia mengadakan supervisi yang baik dalam rangka memberi bantuan dalam menentukan kebutuhan-kebutuhan sekolah dan diusahakan dilaksanakan kearah perubahan yang diinginkan. ${ }^{7}$

Sejalan dengan hal tersebut manajemen menuntut perubahanperubahan tingkah laku kepala sekolah, guru dan tenaga administrasi dalam mengoperasikan sekolah. Pelaksanaan manajemen berpotensi meningkatkan gesekan peranan yang bersifat professional dan manajerial. Untuk memenuhi persyaratan pelaksanaan tersebut, kepala sekolah, guru dan tenaga administrasi harus memiliki kedua sifat yaitu, professional dan manajerial. Mereka harus memiliki pengetahuan yang dalam tentang peserta didik dan prinsip-prinsip pendidikan untuk menjamin bahwa segala keputusan penting yang buat oleh sekolah, didasarkan atas pertimbangan- pertimbangan pendidikan. Kepala sekolah khususnya perlu mempelajari dengan teliti, baik kebijakan dan prioritas pemerintah maupun prioritas sekolah sendiri. ${ }^{8}$ Memandang bahwa dalam dunia pendidikan, analisis situasi harus ditindaklanjuti dengan penggunaan tenik analisis SWOT, meliputi

7 Soekarto Indra Fachrudi dkk, Administrasi Sekolah (Malang: Departemen Administrasi Pendidikan Fakultas Ilmu Pendidikan IKIP Malang,1975), hal. 1.

${ }^{8}$ E. Mulyasa, Manajemen \& Kepemimpinan Kepala Sekolah (Jakarta : Bumi Aksara, 2012) h. 21 cet. 13 . 
aktivitas evaluasi terhadap kekuatan dan kelemahan internal sistem pendidikan serta peluang dan ancaman yang berasal dari luar sistem pendidikan. Situation audit didasarkan pada nilai-nilai, dukungan, dan kemampuan yang ada. Dengan demikian, akan dapat diketahui kekuatan dan kelemahan, serta kebutuhan-kebutuhan yang belum terpenuhi dalam penyelenggaraan pendidikan.

Substansi perencanaan terkandung dalam empat hal di atas, berisi akumulasi informasi hasil analisis situasi atau bagian dari perencanaan berupa corporate appraisal, position audit, assessment of current position, and planning premises. Dalam hal ini perlu dipertimbangkan : harapan-harapan masyarakat di luar sistem, harapan manajer dan tenaga kependidikan organisasi, database yang berisi informasi tentang past performance, the current situation, and the future, melakukan analisis dengan menggunakan teknik TOWS analysis.

Langkah berikutnya adalah memformulasikan master strategis dan program strategis. Master strategis meliputi kegiatan pengembangan misi utama, tujuan dan kebijakan, sedangkan program strategis menyangkut pengadaan, penggunaan dan pengaturan sumber-sumber untuk kepentingan suatu kegiatan. Bidang kajiannya meliputi semua aktivitas organisasi.

Kondisi tersebut menunjukkan perlunya berbagai upaya perbaikan untuk meningkatkan mutu pendidikan, melalui manajemen yang tepat, sesuai dengan kebutuhan masyarakat dan pembangunan.

\section{B. Pembahasan}

\section{Konsep Manajemen Strategik}

Mutu pendidikan, sebagai salah satu pilar pengembangan sumber daya manusia sangat penting maknanya bagi pembangunan nasional. Bahkan dapat dikatakan masa depan bangsa terletak pada keberadaan pendidikan yang berkualitas pada masa kini, pendidikan yang berkualitas hanya akan muncul apabila terdapat lembaga pendidikan yang berkualitas. Karena itu, upaya peningkatan mutu pendidikan merupakan titik strategi dalam upaya untuk menciptakan pendidikan yang berkualitas.

Manajemen peningkatan mutu pendidikan merupakan suatu metode peningkatan mutu yang bertumpu pada lembaga itu sendiri, 
mengaplikasikan sekumpulan teknik, berdasarkan pada ketersediaan data kualitatif dan kuantitatif dan pemberdayaan semua komponen lembaga pendidikan untuk secara berkesinambungan meningkatkan kapasitas dan kemampuan organisasi guna memenuhi kebutuhan peserta didik masyarakat.

Kontek manajemen istilah strategik diartikan sebagai cara taktik utama yang dirancang secara sistematik dalam melaksanakan fungsi manajemen yang terarah pada tujuaj strategik organisasi. Rancangan ini disebut sebagai perencanaan strategik. Manajemen strategik adalah proses formulasi dan implementasi rencana dan kegiatan yang berhubungan dengan hal-hal vital, perpasif dan berkesinambungan bagi suatu organisasi secara keseluruhan. ${ }^{9}$

Perkembangan yang terjadi dalam berbagai kehidupan cendrung menimbulkan permasalahan dan tantangan-tantangan baru, yang variasi dan intensitasnya cendrung meningkat. Keadaan itu akan membawa dampak pada luas dan bervariasinya tugas-tugas pengelolaan pendidikan. Praktis pengelolaan pendidikan dewasa ini sudah tidak memadai lagi untuk menangani perkembangan yang ada, apalagi untuk menjangkau jauh ke depan sesuai dengan tuntunan terhadap peranan pendidikan yang sesungguhnya, maka kebutuhan akan aplikasi konsep Strategic Manajement \& Strategic Planing dalam pengelolaan pendidikan amat diperlukan. Aplikasi konsep tersebut diharapkan dapat mengurangi adanya stagnansi bagi akselerasi pembangunan pendidikan. ${ }^{10}$

Konsep-konsep dan prinsip-prinsip dasar tentang manajemen strategik dikemukakan oleh Wheelen and Hunger (1995) sebagai berikut : (1) Manajemen strategik merupakan serangkaian keputusan dan tindakan menajerial yang menentukan kinerja perusahaaan dalam jangka panjang. Manajemen strategik meliputi pengamatan lingkungan, perumusan strategi, implementasi strategi serta evaluasi dan pengendalian. (2) manajemen strategi menekankan pada pengamatan dan evaluasi kesempatan (opportunity) dan ancaman (threat), lingkungan dipandang dari sudit kekuatan (strength) dan

${ }^{9}$ Ibid, h. 160.

${ }^{10}$ Ibid, h. 160-161. 
kelemahan (weakness) variable-variabel internal dan eksternal yang paling penting untuk perusahaan dimasa yang akan dating disebut factor strategis dan diidentifikasi melalui analis SWOT. (3) keputusan starategis berhubungan dengan masa yang akan dating dalam jangka panjang untuk organisasi secara keseluruhan dan memiliki tiga karakteristik, yaitu rare, consequential dan directive. Rare merupakan keputusan-keputusan strategik yang tidak biasa dan khusus, serta tidak dapat ditiru, consequential, merupakan keputusan-keputusan strategis yang memasukkan sumber daya penting dan menuntut banyak komitmen. Directive merupakan keputusan-keputusan lain dan tindakan-tindakan di masa yang akan datang untuk organisasi secara keseluruhan. (4) manajemen strategis pada banyak organisasi cendrung dikembangkan dalam empat tahap, mulai dari perencanaan keuangan dasar ke perencanaan berbasis peramalan yang biasa disebut perencanaan strategis menuju manajemen strategis yang berkembang sepenuhnya, termasuk implementasi, evaluasi dan pengendalian.

Komponene - komponen dan struktur manajemen strategis mencakup pengamatan lingkungan, perumusan strategis, implementasi strategi, serta evaluasi dan pengendalian. Hal tersebut di gambarkan sebagai berikut :

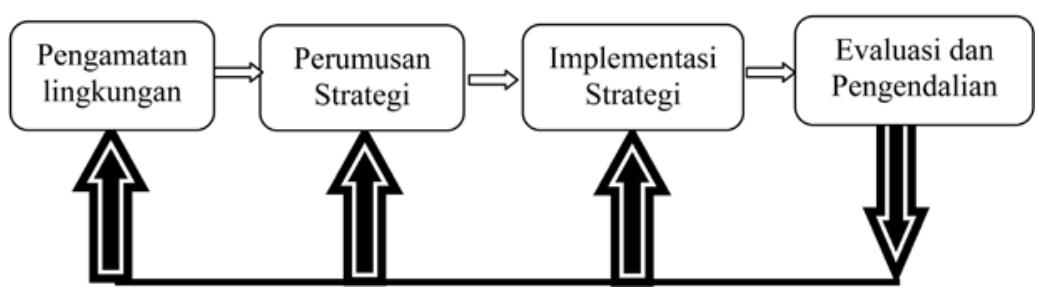

Sumber: Manajemen dan Kepemimpinan Kepala Sekolah

Sedikitnya terdapat tiga langkah utaman pendekatan strategi dalam konteks manjemen, meliputi : perencanaan strategi, sumbersumber yang diperlukan dan struktur organisasi. ${ }^{11}$

${ }^{11}$ Ibid, h.162. 


\section{Implementasi Manajemen Strategik}

Implementasi strategik adalah proses manajemen mewujudkan strateginya dalam bentuk program, prosedur, anggaran serta pengembangan strategi dalam bentuk tindakan. Visi merupakan suatu proses yang menggambarkan serangkaian kegiatan perencanaan dan penetapan sasaran sekolah secara formal dan misi adalah alasan keberadaan suatu lembaga. ${ }^{12}$ Strategi adalah sebuah rencana yang komprehensif mengintegrasikan segala resources dan capabilities yang mempunyai tujuan jangka panjang untuk memenangkan kompetisi. Betapapun hebatnya suatu visi, misi, dan strategi bila tidak diimplementasikan tentu saja strategi itu tidak akan bermakna bagi pengembangan sekolah.

Berdasarkan uraian mengenai konsep manajemen strategik di atas disimpulkan karakteristik manajemen strategik adalah : (1) Manajemen strategik diwujudkan dalam bentuk perencanaan berskala besar, dalam arti mencakup kepentingan seluruh komponen organisasi. Hasil rumusan rencana ini biasanya dituangkan dalam bentuk rencana-rencana organisasi secara hierarkis, yakni : rencana strategis (renstra), rencana operasional (renop), program dan kegiatan, (2) rencana strategik berorientasi kemas depan (misal 10 tahun ke atas), (3) visi dan misi organisasi menjadi acuan dalam penyusunan rencana strategis, (4) adanya keterlibatan pimpinan puncak dalam penyusunan rencana strategis, (5) hasil rumusan rencana strategis diimplementasikan melalui fungsi manajemen.

Manajemen strategik memiliki dimensi yang bersifat multi dimensional, yaitu : (1) dimensi waktu dan orientasi maa depan. Manajemen strategi berorientasi kepada sasaran jangka panjang. Antisipasi masa depan tersebut dirumuskan dan ditetapkan sebagai visi organisasi yang akan diwujudkan 10 tahun atau lebih di masa depan. Durasi waktu rencana strategis tersebut bahkan dapat berkisar antara 25-30 tahun ke atas, (2) dimensi internal dan eksternal, (3) dimensi pendayagunaan sumber-sumber, (4) dimensi multi bidang, (5) pengikutsertaan manajemen puncak.

${ }^{12}$ Yodhia Antariksa, Melejitkan Kinerja Bisnis dengan Formula 7S, blog strategi \& manajemen, 7S yodia htm, diakses 2 April 2014. 
Sebagai salah satu bentuk jasa yang melibatkan intraksi antara penyedia dan pemakai jasa, terdapat lima dimensi pokok yang menentukan kualitas penyelenggaraan pendidikan yaitu; ${ }^{13}$ pertama keadaaan (reliability), yakni kemampuan memberikan pelayanan yang djanjikan secara tepat waktu, akurat dan memuaskan. Kedua daya tangkap (responsiveness), yaitu kemauan para tenaga kependidikan untuk membantu para peserta didik dan memberikan layanan dengan tanggap. Ketiga jaminan (assurance) mencakup pengetahuan, kompetensi, kesopanan, respek terhadap pelanggan, dan sifat dapat dipercaya yang dimiliki para tenaga kependidikan, bebas dari bahaya, risiko atau keragu-raguan. Keempat empati, kemudahan dalam melakukan hubungan, komunikasi yang baik, perhatian pribadi, dan memahami kebutuhan para pelanggan. Kelima bukti langsung (tangibles), meliputi fasilitas fisik, perlengkapan, tenaga kependidikan dan sarana komunikasi.

Urutan kelima dimensi di atas didasarkan pada derajat kepentingan relatifnya di mata pelanggan. Dimenis-dimensi ini digunakan pelanggan untuk menilai kualitas jasa (service quality) dan jasa yang dipersiapkan merupakan ukuran kualitas jasa. ${ }^{14}$

\section{Kurikulum Pendidikan Islam dalam Manajemen Strategik}

Sebagaimana kita fahami bersama bahwa wahyu yang pertama di terima Nabi Muhammad SAW, adalah surat al-Alaq ayat 1-5 yang artinya:"Bacalah dengan (menyebut) nama Tuhanmu yang Menciptakan, Dia telah menciptakan manusia dari segumpal darah. Bacalah, dan Tuhanmulah yang Maha pemurah, yang mengajar (manusia) dengan pena, Dia mengajarkan manusia apa yang tidak diketahuinya." (Q.S. AlAlaq : $1-5)^{15}$

Kemudian di perkuat dengan ayat lain pada Al-Qur'an surat AlMuzammil 1-4 yang artinya sebagai berikut: "Wahai orang yang

${ }^{13}$ Ibid, h. 167-168.

${ }^{14}$ Ibid, h. 169.

${ }^{15}$ Kementrian Agama RI, Alquran dan Terjemahnya (Bandung: CV Penerbit Diponegoro, 2008), h.579.

${ }^{15}$ Ibid, h.597. 
berselimut (Muhammad), bangunlah (untuk sholat) pada malam hari, kecuali sebagian kecil, (yaitu) seperuhnya atau kurang sedikit dari itu, atau lebih dari (seperdua) itu, dan bacalah Al Quran itu dengan perlahan-lahan" (Q.S Al-Muzammil 1-4). ${ }^{16}$

Menurut Mahmud Yunus dalam Ahmad Tafsir dalam kedua wahyu tersebut dapat diambil pengertian bahwa dalam pendidikan Islam ada tiga aspek kepribadian manusia yang harus dibina atau didik, yaitu; ${ }^{17}$ pertama aspek jasmani, yaitu mementingkan kebersihan, kedua aspek akal, yaitu segi pembinaan kecerdasan dan pemberian pengetahuan ini dijelaskan dalam ayat yang menyuruh mempelajari kejadian manusia, ketiga aspek ruhani, yaitu pembinaan segi keagamaan. Ini dijelaskan oleh ayat yang menyuruh membaca dengan nama Allah, Tuhan yang Maha Pemurah mengagungkan Tuhan. Termasuk ruhani juga adalah pendidikan akhlak, yang dijelaskan agar suka memberi dan tanpa mengharapkan balasan yang banyak agar bersabar dan tabah dalam melaksanakantugas.

Dari uraian tersebut diatas sehingga penulis dapat mengambil benang merah inti dari kurikulum pembelajaran Islam, sebagaimana pada gambar di bawah ini;

Gambar 1.1 Kurikulum pendidikan Islami

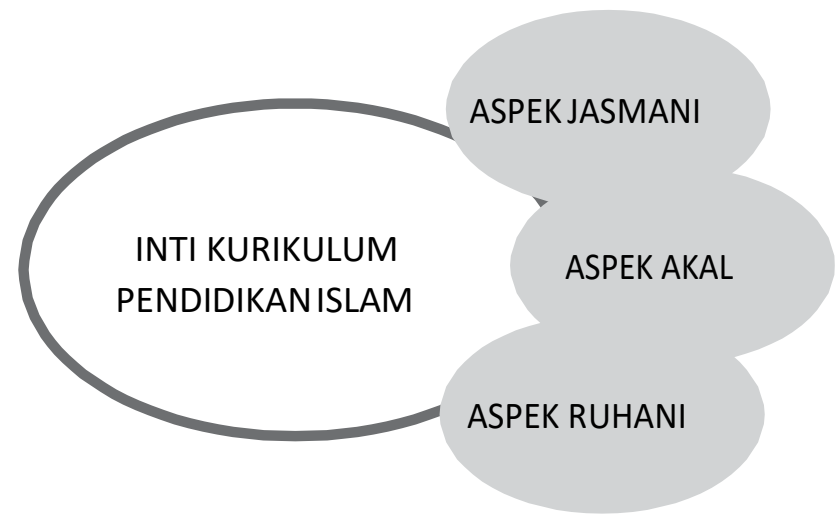

${ }^{16}$ Ibid, h. 574.

${ }^{17}$ Ibid, h. 87. 
Kebanyakan orang beranggapan bahwa mengelola lembaga pendidikan agama tidak perlu mendapat perhatian dan penanganan khusus sebab out-put-nya kurang dapat diandalkan untuk berkompetisi dalam masyarakat jika dibanding out-put lembaga pendidikan lain. Secara administratif, lembaga pendidikan Islam yang benar-benar menerapkan manajemen strategik pendidikan dengan baik sangat jarang sekali. Salah satu hal yang sangat berkaitan dengan lembaga pendidikan adalah lingkungan pendidikan yang menjadi salah satu sarana seorang anak dapat memperoleh pendidikan dengan baik.

\section{Pembelajaran Islam dengan Konsep Manajemen Strategik}

Dalam sebuah hadist disebutkan :

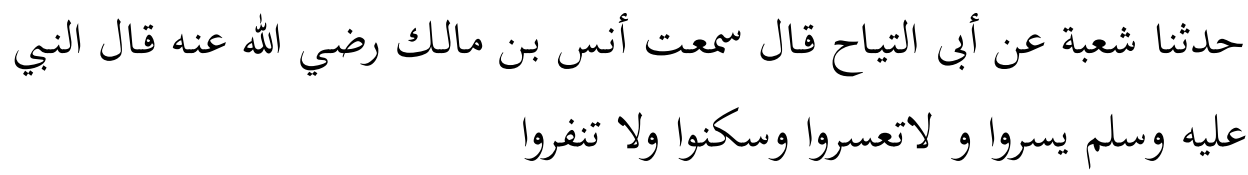

Telah menceritakan kepada kami Adam telah menceritakan kepada kami Syu'bah dari Abu At Tayyah dia berkata; saya mendengar Anas bin Malik radliallahu 'anhu berkata; Nabi shallallahu 'alaihi wasallam bersabda: "Mudahkanlah setiap urusan dan janganlah kalian mempersulitnya, buatlah mereka tenang dan jangan membuat mereka lari." 18

Hadist di atas menjelaskan bahwa proses pembelajaran harus dibuat dengan mudah sekaligus menyenangkan agar siswa tidak tertekan secara psikologis dan tidak merasa bosan terhadap suasana di kelas, serta apa yang diajarkan oleh gurunya. Dan suatu pembelajaran juga harus menggunakan metode yang tepat disesuaikan dengan situasi dan kondisi, terutama dengan mempertimbangkan keadaan orang yang akan belajar. ${ }^{19}$

${ }^{18}$ Abu Abdillah Al-Bukhari, Shahih Al-Bukhari, (Lebanon: Dar al-Ilm, t.t.), juz 1, h. 111.

${ }^{19}$ Ismail SM., Strategi Pembelajaran Agama Islam Berbaisis PIKEM (Semarang: Rasail Media Group, 2008), h. 13. 
Meskipun dalam Islam banyak hal yang telah dimudahkan oleh Allah akan tetapi perlu diperhatikan bahwa maksud kemudahan Islam bukan berarti kita boleh menyepelekan syari'at Islam dalam hal pendidikan, mencari-cari ketergelinciran atau mencari pendapat lemah sebagian ulama agar kita bisa seenaknya, namun kemudahan itu diberikan dengan alasan agar kita selalu melaksanakan perintahNya dan menjauhi larangan-Nya.

Tampaknya tidak dapat disangkal lagi bahwa keluarga memunyai pengaruh yang besar dalam sosialisasi pendidikan karakter bagi anak -anak. Namun, juga adanya fakta bahwa semakin banyak bukti yang menunjukkan bahwa sekolah dapat membuat perbedaan dalam pngembangan karakter anak-anak. ${ }^{20}$

Manusia, di samping makhluk beragama, adalah makhluk sosial, yaitu makhluk yang selalu hidup bermasyarakat dan senantiasa membutuhkan peran-serta pihak lain. Artinya, berinteraksi sosial atau hidup bermasyarakat merupakan sesuatu yang tumbuh sesuai dengan fitrah dan kebutuhan kemanusiaan. Dalam hal ini, al-Qur`an banyak memberikan arahan atau nilai- nilai positif yang harus dikembangkan; juga nilai-nilai negatif yang semestinya untuk dihindarkan. ${ }^{21}$

Kini makin disadari pentingnya mengubah paradigm pembelajaran, termasuk juga dalam menilai hasil belajar atau penguasaan oleh pembelajar. Pembelajaran bukan lagi proses mentransfer pengetahuan dari mereka yang diakui memiliki pengetahuan dalam hal ini pendidik (ustad, guru, kiyai) kepada orang yang dididik (santri, murid). Di beberapa Negara, dikembangkan paradigm baru pembelajaran yang penting kita perhatikan untuk kita periksa dan kita telaah kemungkinannya diterapkan dalam dunia pendidikan Islam dan tanah air. ${ }^{22}$

Menurut Achmad Sanusi konsep pembelajaran di dalam manajemen strategik dikategorikan dalam tiga hal yaitu; “(1) Berkaitan dengan paradigma baru pembelajaran seperti yang dikemukakanJohn Jay

${ }^{20}$ Cut Zahri Harun, “Manajemen Pendidikan Karakter”, no. 3, h. 304

${ }^{21}$ Dian Iskandar Jaelani, “ Manajemen Public Relations (Humas) Pendidikan Islam”. Kajian Tematik Al Quran dan Hadits, vol. 3. No. 2, h. 65

${ }^{22}$ Achmad Sanusi, Pembaharuan Strategi Pendidikan, Filsafat, Manajemen, dan Arah Pembagunan Karakter Bangsa (Bandung : Nuansa Cendekia, 2014), h. 178 cet.I. 
Bonstingl yang sebelumnya juga disajikan dalam Schools of Quality: An Introduction to Total Quality Management in Education. (2) Konsep multiple inteligencies, (3) Konsep berfikir”. ${ }^{23}$

Dari Bonsting, kita mengkaji bagaiman pergeseran dari pengajaran dan pengujian menjadi pembelajaran berkelanjutan dan perbaikan berkelanjutan, seperti yang disajikan berikut ini:

\begin{tabular}{|c|c|}
\hline $\begin{array}{c}\text { Paradigm Lama Pengajaran Dan } \\
\text { Pengajuan }\end{array}$ & $\begin{array}{c}\text { Paradigm baru Pembelajaran } \\
\text { Berkelanjutan } \\
\text { Dan perbaikan keberlanjutan }\end{array}$ \\
\hline $\begin{array}{l}\text { Keberhasilan secara artifial dibatasi } \\
\text { hanya milik segelintir } \\
\text { “pemenang”. Siswa lainnya dibuat } \\
\text { untuk memandang dirinya dan } \\
\text { karya- karyanya hanya sebagai } \\
\text { kelompok pertengahan dan } \\
\text { kelompokbawah }\end{array}$ & 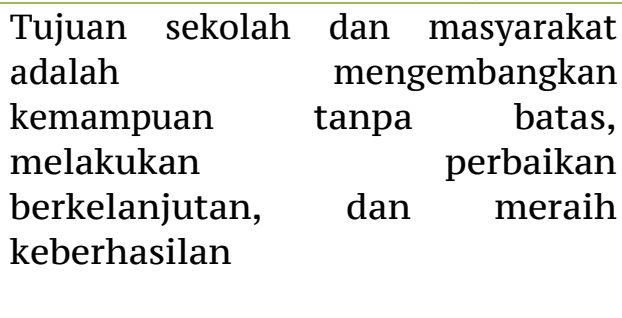 \\
\hline Berbasis Kompetisi & Berbasis kooperasi \\
\hline $\begin{array}{l}\text { Pembelajaran bersifat linear, } \\
\text { yang bagian-bagiannya } \\
\text { secara berurutan } \\
\text { komunikasi satu arah }\end{array}$ & $\begin{array}{l}\text { Pembelajaran seperti spiral } \\
\text { dengan berbagai cabang dan } \\
\text { bagiannya, dengan energi yang } \\
\text { diarahkan menuju perbaikan } \\
\text { berkelanjutan. }\end{array}$ \\
\hline $\begin{array}{l}\text { Berorientasi pada produk. Fo } \\
\text { tunggalnya adalah hasil tar } \\
\text { mengakui watak jan } \\
\text { pendeknya. Kelas dan pering } \\
\text { menjadibagian sangat penting }\end{array}$ & $\begin{array}{l}\text { Berorientasi pada proses. Tujuan } \\
\text { adalah hal yang penting, namun } \\
\text { proses mencapai tujuan juga tak } \\
\text { kalah pentingnya. Asesmen } \\
\text { dipakai untuk tujuan melakukan } \\
\text { diagnosis dan preskripsi. }\end{array}$ \\
\hline $\begin{array}{l}\text { Hidup, termasuk sekolah, hanya } \\
\text { bermakna bila kita bisa mencapai } \\
\text { tujuan. Proses dipandang hanya } \\
\text { memiliki sedikit nilai intrinsik atau } \\
\text { bahkan tidak penting sama sekali, } \\
\text { dan harus dibuat seringkas }\end{array}$ & $\begin{array}{l}\text { Hidup merupakan sebuah } \\
\text { perjalanan dan memiliki nilai } \\
\text { intrinsik bila dilakoni dengan } \\
\text { semangat untuk hidup itu sendiri, } \\
\text { cinta kasih, dan belajar. Hal yang } \\
\text { paling penting adalah }\end{array}$ \\
\hline
\end{tabular}

${ }^{23}$ Ibid, $178-179$. 


\begin{tabular}{|l|l|}
$\begin{array}{l}\text { mungkin sehingga tujuan bisa } \\
\text { tercapaisecepat mungkin. }\end{array}$ & $\begin{array}{l}\text { mengembangkan "hasrat untuk } \\
\text { terus belajar”. }\end{array}$ \\
\hline $\begin{array}{l}\text { Sistem dan prosesnya tidaklah } \\
\text { terlalu penting, sejauh tujuan } \\
\text { bisa dicapai. }\end{array}$ & $\begin{array}{l}\text { Integritas dan kesehatan sistem, } \\
\text { proses-proses yang berlangsung } \\
\text { didalamnya dan orang-orang } \\
\text { yang terlibat harus dijaga. Kalau } \\
\text { tidak, sistem bisa-bisa bekerja tidak } \\
\text { optimal dan bahkan bisa saja gagal }\end{array}$ \\
\hline $\begin{array}{l}\text { Bekerja adalah menjalankan tugas, } \\
\text { bukan memberi } \\
\text { kesenangan dan martabat bagi } \\
\text { parapekerja. }\end{array}$ & $\begin{array}{l}\text { Pekerjaan harus menantang, } \\
\text { menyenangkan, dan bermakna. } \\
\text { Para pekerja hendaklah meraih } \\
\text { martabat dan kegembiraan dalam } \\
\text { proses menjalankan pekerjaannya } \\
\text { dan menghasilkan produk. }\end{array}$ \\
\hline
\end{tabular}

Paradigma baru pembelajaran tersebut jelas menunjukkan bahwa yang terpenting dari pembelajaran adalah orang menjadi pembelajar sepanjang hayat dan terus melakukan perbaikan pada dirinya.Selanjutnya kegiatan dan teknik pembelajaran dari konsep kecerdasan jama' (multiple intellegenses). Kecerdasan jama' ini melihat potensi yang dimiliki manusia yang cukup beragam. Sebagaimana Allah berfirman dalam surat Al-Baqoroh ayat 44 dan 164 yang artinya:"Mengapa kamu menyuruh orang lain (mengerjakan) kebajikan, sedangkan kamu melupakan dirimu sendiri, padahal kamu membaca kitab (Taurat)? Tidakah kamu mengerti?” (QS. Al-Baqarah : 44) ${ }^{24}$

"Sesungguhnya pada penciptaan langit dan bumi, pergantian malam dan siang, kapal yang berlayar di laut dengan (muatan) yang bermanfaat bagi manusia, apa yang diturunkan Allah dari langit berupa air, lalu dengan itu dihidupkan-Nya bumi setelah mati (kering, dan Dia tebarkan di dalamnya bermacam-macam binatang, dan perkisaran angin dan awan yang dikendalikan antara langit dan

${ }^{24}$ Kementrian Agama RI, Alquran dan Terjemahnya (Bandung: CV Penerbit Diponegoro, 2008), h.7. 
bumi, (semua itu) sungguh, merupakan tanda-tanda (kebesaran Allah) bagi orang-orang yang mengerti." (QS. Al-Baqarah 164). ${ }^{25}$

Ditegaskan juga oleh hadist Nabi Muhammad saw, yang diriwayatkan Imam Tirmidzi yang artinya sebagai berikut:"Dari Syaddad Ibn Aus, darr Rasulullah saw. Bersabda : orang yang cerdas adalah orang yang merendahkan dirinya dan beramal untuk persiapan sesudah mati." 26

Al-Mawardi dalam kitab Adab ad-Dunya wa ad-Ddin pada bab pertama menjelaskan tentang keutamaan akal, bahwa segala yang mulia memilki asas dan segala etika memiliki sumber, asas bagi segala kemuliaan dan sumber bagi segala etika adalah akal. Lebih lanjut AlMawardi menyimpulkan definisi akal yaitu pengetahuan tentang halhal yang diketahui secaralangsung. ${ }^{27}$

Selanjutnya, kita melihat bagaimana soal berfikir, dalam hal ini Al-Qur'an telah menyebut \pm 36 kali untuk selalu berfikir menggunakan akal, salah satu contoh pada surat Az-Zumar : 43 yang artinya:"Ataukah mereka mengambil penolong selain Allah. Katakanlah, “Apakah (kamu mengambilnya juga) meskipun mereka tidak memiliki sesuatu apa pun dan tidak mengerti?” (Az-Zumar : 43). ${ }^{28}$

Sehingga sangat jelas bahwa siswa harus dilatih dan diberi kebebsan untuk selalu berfikir positif dalam pembelajaran, pada tahun 1990-an berkembang sejumlah penelitian yang menunjukkan pembelajaran berfikir mendorong prestasi belajar siswa dan hasil belajar yang lebih baik. ${ }^{29}$ Tidak mengherankan bila kemudian banyak pakar yang mendorong dan mengingatkan pentingnya pendidikan berpikir.

${ }^{25}$ Ibid, h. 25.

${ }^{26}$ At-Tarmizi, Sunan At-Tarmizi, (Beirut, Dar al-Arab al-Islami, 1998), juz 4, h. 638.

${ }^{27}$ Al-Mawardi, Adab ad-Dunya wa ad-Din, (Beirut, Dar al-Fikr, 1995), h. 19.

${ }^{28}$ Kementrian Agama RI, Alquran dan Terjemahnya (Bandung: CV Penerbit Diponegoro, 2008), h. 463.

${ }^{29}$ Ahmad Sanusi, Pembaharuan Strategi Pendidikan, Filsafat, Manajemen, dan Arah Pembangunan Karakter Bangsa (Bandung: Nuansa Cendikia, 2014), h. 184, cet 1. 


\section{Evaluasi Pembelajaran Melalui Pendekatan Starategi}

Dalam buku pedoman penilaian kurikulum 1994, dikemukakan bahwa:"Penilaian adalah suatu kegiatan yang dilakukan oleh guru untuk memberikan berbagai informasi secara berkesinambungan dan menyeluruh tentang proses dan hasil belajar yang telah dicapai siswa Nana Sudjana mengatakan penilaian merupakan proses memberikan atau menentukan nilai kepada objek tertentu berdasarkan suatu kriteria tertentu. ${ }^{30}$ Seperti yang sudah kita ketahui bahwa penilaian terdiri dari tiga ranah yaitu kognitif, afektif dan psikomotor, yang masing-masing ranah terdiri dari sejumlah aspek yang saling berkaitan. Alat dan penilaiannya untuk setiap ranah tersebut mempunyai karakteristik tersendiri sebab setiap ranah berbeda dalam cakupan dan hakikat yang terkandung di dalamnya.

Tugas-tugas asesmen kinerja menuntut siswa menggunakan berbagai macam keterampilan, konsep, dan pengetahuan. Asesmen kinerja tidak dimaksudkan untuk menguji ingatan faktual, melainkan untuk mengakses penerapan pengetahuan faktual dan konsep-konsep ilmiah pada suatu masalah atau tugas yang realistik. Asesmen tersebut meminta siswa untuk menjelaskan "mengapa atau bagaimana" dari suatu konsep atau proses. Asesmen kinerja merupakan suatu komponen penting dari suatu asesmen autentik.

Bentuk asesmen dimana siswa menunjukkan atau mendemonstrasikan suatu respon secara lisan, tertulis, atau menciptakan suatu karya. Respon siswa tersebut dapat diperoleh guru dalam konteks asesmen formal atau informal atau dapat diamati selama pengajaran di kelas atau seting di luar pembelajaran. Meminta siswa untuk "menyelesaikan tugas-tugas kompleks dan nyata dengan mengerahkan pengetahuan awal, pembelajaran yang baru diperoleh, dan keterampilan-keterampilan yang relevan untuk memecahkan masalah realistik atau autentik" Memungkinkan siswa menggunakan bahan-bahan atau melakukan kegiatan hands-on dalam mencapai pemecahan masalah. Contohnya adalah laporan-laporan lisan, contoh-contoh tulisan, proyek individual atau kelompok, pameran, atau demonstrasi.

${ }^{30}$ Pedoman Penilaian Kurikulum 1994 (Depdikbud : 1994), h. 56. 
Hibbard menyatakan asesmen kinerja merupakan: Suatu realitas yang terkait dengan tujuan pendidikan sains. Komponen utama program pendidikan bertujuan: (1) menanamkan konsep dan informasi; (2) mengembangkan proses ilmiah, seperti eksperimen, membuat keputusan, membangun model, dan penemuan mesin; (3) mengembangkan keterampilan memecahkan masalah yang melibatkan ilmu pasti dan informasi untuk mendukung metode ilmiah; (4) mengembangkan keterampilan komunikasi untuk membantu siswa menanamkan hal-hal lain secara efektif apa yang mereka telah pelajari atau apa yang menjadi saran mereka sebagai solusi masalah; (5) menanamkan kebiasaan bekerja dengan baik, seperti bertanggungjawab secara individu, keterampilan bekerja sama, tekun, memperhatikan keakuratan dan kualitas, jujur, memperhatikan keamanan, dan rapi. Suatu sistem untuk menilai proses dan produk.

Asesmen kinerja merupakan suatu sistem untuk menilai kualitas penyelesaian tugas-tugas yang diberikan siswa. Tugas-tugas kinerja seperti: (1) pentingnya aplikasi konsep sains dan mendukung informasi; (2) pentingnya kebiasaan bekerja mengkaji atau mencari secara ilmiah; (3) demonstrasi melek sains. Adapun komponen sistem asesmen kinerja termasuk: (1) tugas-tugas yang menanyakan siswa untuk menggunakan dan proses mereka yang telah dipelajari; (2) cheklist untuk mengidentifikasi elemen kinerja atau hasil pakerjaan; (3) Rubrik (perangkat yang mendeskripsikan proses dan atau kesatuan penilaian kualitas) berdasarkan skor total; (4) contoh-contoh terbaik sebagai model kerja yang akan dikerjakan.

Penilaian kerja ialah penilaian kerja yang dilandaskan pada pengamatan selama proses peragaan kemampuan atau pada evaluasi penciptaan produk yang dihasilkan. Dalam pedoman penilaian di SD/MI, dinyatakan bahwa tes kinerja adalah tes yang penugasannya disampaikan dalam bentuk lisan atau tertulis dan proses penilaiannya dilakukan sejak siswa melakukan persiapan, melaksanakan tugas sampai dengan hasil akhir . ${ }^{31}$ Penilaian kerja ialah penilaian kerja yang dilandaskan pada pengamatan selama proses peragaan kemampuan atau pada evaluasi penciptaan produk yang dihasilkan. Penilaian kinerja pada

${ }^{31}$ Ibid, h. 8. 
prinsipnya lebih ditekankan pada proses keterampilan dan kecakapan dalam menyelesaikan tugas yang diberikan. Penilaian ini cocok digunakan untuk menilai kompetensi yang menuntut peserta didik melakukan tugas tertentu seperti: praktek di laboratorium, praktek sholat, praktek olahraga, bermain peran, memainkan alat musik, bernyanyi, membaca puisi/ deklamasi dan lain-lain. Cara penilaian ini dianggap lebih otentik daripada tes tertulis karena apa yang dinilai lebih mencerminkan kemampuan peserta didik yang sebenarnya. Berdasarkan cara melaksanakannya penilaian kinerja siswa dapat di kelompokkan menjadi tiga yaitu: (1) Asesmen kinerja klasikan digunakan untuk mengases kinerja siswa secara keseluruhan, (2) Asesmen kinerja kelompok untuk mengakses kinerja siswa secara berkelompok, (3) Asesmen kinerja individu untuk mengangses kinerja siswa individu.

Disamping itu pada penilaian terdapat prinsip-prisipnya yang meliputi; validitas, reliabilitas, menyeluruh, berkesinambungan, obyektif dan mendidik. Ranah penilaian dalam kurikulum tingkat satuan pendidikan (KTSP) merupakan penjabaran dari standar isi dan standar kompetensi lulusan. Di dalamnya memuat kompetensi secara utuh yang merefleksikan pengetahuan, keterampilan dan sikap sesuai karakteristik masing-masing materi pelajaran.

1. Indikator Kinerja. Harus spesifik \& jelas untuk menghindari kesalahan interpretasi, dapat diukur secara objektif baik secara kualitatif maupun kuantitatif, menangani aspek-aspek yang relevan, harus penting berguna untuk menunjukkan keberhasilan, input, output, outcame maupun dampak serta proses fleksibel \& sensitif terhadap perubahan pelaksanaan.

2. Kelebihan dan Kekurangan Penilain Kinerja. Semua jenis penilaian mempunyai kelebihan dan kekurangannya masing- masing namun tergantung guru yang melaksanakan evaluasi, karena jenis evaluasi yang diterapkan sangat tergantung pada kondisi dan tujuan pembelajaran. Namun berikut ini beberapa kelebihan dalam penilaian kelas, yaitu dapat memecahkan masalah, dapat menilai pengetahuan, sikap,dan keterampilan siswa, dapat mendemontrasikan suatu proses, proses yang didemontrasikan dapat diobservasi langsung, penalaran, lugas (fleksibel), komunikasi dalam bentuk lisan dan tulisan, memberi motivasi yang besar bagi 
siswa, mendorong aplikasi pembelajaran pada situasi kehidupan yang nyata.

Supaya nampak lebih jelas penulis mencoba mensistematisasikan dalam bentuk gambar bahwa evaluasi pembelajaran pendidikan Islam menekankan aspek sebagaimana pada gambar di bawah ini;

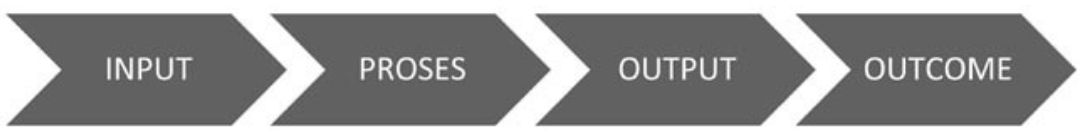

Gambar 1.2 Komponen Evaluasi

Ketika sebuah rangkaian evaluasi tersebut di lalui dengan baik dan melibatkan semua komponen pendidikan Islam maka tujuan pendidikan islam secara paripuna akan tercapai, karena ending akhir pendidikan Islam selain cerdas secara kognitif juga berdampak pada kesalehan sosial dan kesalehan ritual.

\section{Mutu Lulusan Pendidikan Islam}

Pandangan Islam lembaga pendidikan harus mampu membawa implikasi bahwa andaikan manusia tidak menerima pendidikan, maka dengan sendirinya ia akan menjadi baik, sebab, oleh Tuhan, manusia telah dibekali potensi kebaikan. ${ }^{32}$ Namun bila manusia menerima pendidikan, maka aspek pendidikan menjadi faktor penentu apakah orang itu menjadi manusia baik atau buruk, sesuai dengan apa yang di terangkan oleh para sahabat bahwa "setiap anak dilahirkan dalam keadaan "fitrah".

Seorang peserta didik harus dikembangkan semua jenis kecerdesannya baik itu intelektual, spiritual, emosional, dan politiknya. Kompetensi penguasaan ilmu yang cukup mencakup tsaqofah Islam maupun ilmu kehidupan, disertai sikap seseorang atas dasar Islam akan membuat ia selalu menyelesaikan segala masalah

${ }^{32}$ Abdullah Idi dan Toto Suharto, Revitalisasi Pendidikan Islam, (Yogyakarta : Tiara Wacana, 2006), h. 95. 
yang dihadapinya sesuai dengan syariat Islam baik itu masalah pribadi, keluarga, masyarakat, dan negara. ${ }^{33}$

Pendidikan Islam akan menghasilkan generasi bangsa yang mampu bersaing di era globalisasi dengan baik sepanjang ia telah memiliki landasan filosofis yang jelas tentang konsepsi manusia, suatu wilayah kajian yang merupakan bidang garap dari filsafat pendidikan Islam. Pendidikan Islam sebagai suatu proses setidaknya memerlukan dua landasan, yaitu landasan filosofis dan landasan ilmiah. ${ }^{34}$

Secara mendasar, tugas utama pendidikan adalah mengubah (transform) potensi dalam diri manusia menjadi kemampuan atau keterampilan yang berdaya guna bagi alam semesta. Potensi intelektual misalnya, akan sia-sia belaka bila hanya disimpan dikepala. Potensi intelektual menjadi berguna jika ia sudah diubah, melalui proses pendidikan, misalnya menjadi penemuan ilmiah diberbagai bidang. Penemuan ilmiah seperti itu merupakan hasil olahan dari upaya pengembangan potensi intelektual manusia yang semula tersembunyi. ${ }^{35}$

Seperti yang telah saya utarakan di atas bahwa pendidikan Islam sesungguhnya adalah solusi bagi penyakit yang menimpa manusia modern. Pendidikan Islam adalah pendidikan yang dibangun atas dasar fitrah manusia. Yang senantiasa bertujuan menumbuhkan kepribadian total manusia secara seimbang melalui latihan spiritual, intelektual, rasional diri, perasaan dan kepekaan tubuh manusia.

Pendidikan Islam identik dikaitkan dengan pendidikan pesantren sebab mampu menghadapi arus perubahan nilai. ${ }^{36}$ Abdul Rahman Wahid, orang yang dianggap cukup mengetahui hal ihwal pesantren, menyampaikan teori Geertz, menurut Gertz kiyai berperan sebagai penyaring arus informasi yang masuk kelingkungan kaum

${ }^{33}$ Oom Mukarromah, “ Peran Teknologi Pendidikan Islam pada Era Global ”, vol. 1, no. 2, h. 97.

${ }^{34}$ Ibid, h. 52.

${ }^{35}$ Ibid, h. 61-62.

${ }^{36}$ Ahmad Tafsir, Ilmu Pendidikan Islami, (Bandung : Remaja Rosdakarya, 2013) h. 296 cet. II. 
santri, menularkan apa yang dianggap berguna dan membuang apa yang dianggap merusak. ${ }^{37}$

Sebenarnya betapapun derasnya arus informasi yang masuk, kiyai tidak akan kehilangan peranannya itu bila ia masih sanggup menjaga pranata-pranata sebagaimana disebut, sehingga melahirkan generasi-generasi yang mempunyai karakter serta memegang nilainilai tawadu', sabar, moderat, dan berwawasan global. Lulusan pendidikan Islam juga mampu bersaing dari tataran lokal, nasional, hingga kancah internasional hal inilah yang mewarnai pendidikan di Indonesia.

\section{Simpulan}

Pengamatan dan penilaian yang dilakukan secara simultan terhadap lingkungan eksternal dan internal lembaga pendidikan memungkinkan para pengelola pendidikan mampu mengidentifikasi berbagai jenis peluang untuk merumuskan dan mengimplementasikan rencana pendidikan. Rancangan yang bersifat menyeluruh dapat dilakukan melalui proses tindakan yang dikenal sebagai manajemen strategik dan mutu pendidikan Islam.

Konsep manajemen strategik dalam pendidikan Islam memang merupakan hal yang baru sehingga harapan besar pada tulisan ini dapat digunakan di dunia pendidikan Islam yang lebih luas serta lebih mengefektifkan pengalokasian sumber daya yang ada dalam rangka mencapai tujuan pendidikan nasional. Salah satu caranya adalah dengan menggunakan teknik analisis SWOT.

Tidak menutup kemungkinan bahwa berkembangnya pendidikan saat ini khusunya di Indonesia akan dibawa lagi pada konsep-konsep pendidikan Rasulullah saw, tetapi hanya berbeda kemasan, bungkus atau cara penyampaiannya karena di sesuaikan dengan perkembangan IT, budaya masyarakat serta pudarnya generasi bangsa yang acuh terhadap budaya dan karya-karya anak bangsa. Inti (core) dari mutu pendidikan Islam adalah pendidikan jasmani, pendidikan ruhani dan pendidikan aqliyah, sehingga memunculkan generasi yang “Taqorrub Ilallah” untuk

${ }^{37}$ Hiroko Horikoshi, Kyai Dan Perubahan Sosial (Jakarta: P3M, 1987) h. xvi. 
melahirkan insan kamil (manusia yang sempurna), melalui penanaman akhlakul karimah.

Jadi mutu lulusan pendidikan Islam tidak dipandang sebelah mata, justru sangat besar peranannya di lingkungan masyarakat. Maka hal ini diharapkan ketika berangkat dari bawah (botton up) bukan dari atas ke bawah (top down), mampu merambah ke kancah nasional dan berkontribusi pada bangsa. Pendidikan Islam adalah pendidikan yang dibangun atas dasar fitrah manusia. Yang senantiasa bertujuan menumbuhkan kepribadian total manusia secara seimbang melalui latihan spiritual, intelektual, rasional diri, perasaan dan kepekaan tubuh manusia.

\section{Daftar Pustaka}

Abdullah Idi dan Toto Suharto, Revitalisasi Pendidikan Islam. Yogyakarta :Tiara Wacana, 2006.

Achmad Sanusi, Pembaharuan Strategi Pendidikan, Filsafat, Manajemen, dan Arah Pembagunan Karakter Bangsa. Bandung : Nuansa Cendekia, 2014, cet. 1 .

Ahmad Tafsir, Ilmu Pendidikan Islam. Bandung : Remaja Rosdakarya, 2013. Cet. II

Al-Mawardi, Adab ad-Dunya wa ad-Din. Beirut, Dar al-Fikr, 1995.

At-Tarmizi, Sunan At-Tarmizi. Beirut, Dar al-Arab al-Islami, 1998.

Dedi Mulyasa, Pendidikna Bermutu dan Berdaya Saing. Bandung: Rosda 2012 , cet. II

Dian Iskandar Jaelani, “ Manajemen Public Relations (Humas) Pendidikan Islam”. Kajian Tematik Al Quran dan Hadits, vol. 3. No. 2.

E. Mulyasa, Manajemen \& Kepemimpinan Kepala Sekolah. Jakarta : Bumi Aksara, 2012, cet. 13.

H.B Siswanto, Pengantar Manajemen. Jakarta : Bumi Aksara, 2006. 
Hiroko Horikoshi, Kyai Dan Perubahan Sosial (Jakarta: P3M, 1987)

http://multazam-einstein.blogspot.co.id/2013/07/hadits-tentangpendidikan-dan-pengajaran.

Ismail SM., Strategi Pembelajaran Agama Islam Berbaisis PIKEM. Semarang: Rasail Media Group, 2008.

Kementrian Agama RI, Alquran dan Terjemahnya. Bandung: CV Penerbit Diponegoro, 2008.

M. Sukarjo dan Ukim Komarudin, Landasan Pendidikan Konsep dan Aplikasinya. Jakarta: PT Raja Grafindo Persada, 2010.

Oom Mukarromah, “ Peran Teknologi Pendidikan Islam pada Era Global " , vol. 1, no. 2.

Pedoman Penilaian Kurikulum 1994. Depdikbud : 1994

Soekarto Indra Fachrudi dkk, Administrasi Sekolah. Malang: Departemen Administrasi.

Yodhia Antariksa, Melejitkan Kinerja Bisnis dengan Formula 7S, blog strategi \& manajemen, $7 S$ yodia htm. 